\title{
Chapter 7 \\ Milan: A City Lost in the Transition from the Growth Machine Paradigm Towards a Social Innovation Approach
}

\author{
Giuliana Costa, Roberta Cucca and Rossana Torri
}

\subsection{Introduction: Milan and Its Pragmatism in Local Welfare}

Milan is considered to be the economic and financial capital of Italy. The apex of the former industrial triangle with Genoa and Turin in the Fordist era, it was one of the main destinations of internal migration from southern regions during the 1950s-1970s period. Employment demand was very high, and it was a key factor in the social inclusion and upward mobility of newcomers. Employment opportunities also fostered the city's capacity to pragmatically develop and consolidate social

The chapter has been written by the three authors as a joint endeavour, but the main authors of the sections can be identified as follows: G. Costa (Sect. 7.1); R. Cucca (Sect. 7.2); R. Torri (Sect. 7.3); G. Costa, R. Cucca, and R. Torri (Sect. 7.4). The text is based on the analysis of existing literature and on interviews to key informants. We especially thank Giordana Ferri, Monica Moschini, and Sergio Urbani (Fondazione Housing Sociale), Sara Travaglini (Dar Casa Association), Federica Verona (Consorzio Cooperative Lavoratori (CCL) housing policy advisor), Laura Pogliani and Stefania Sabatinelli (Polytechnic of Milan), Maurizio Castelnuovo (LegaCoop Abitanti), Francesca Gatto (Municipality of Milan), Gianluca Nardone (KCity), Francesco Minora (European Research Institute on Cooperative and Social Enterprises, Euricse), Lucia Castellano (councillor for housing, state property, and public works for the Municipal Council of the City of Milan), and Ada Lucia De Cesaris (councillor for urban planning, private building and agriculture of the City of Milan).

G. Costa $(\bowtie) \cdot$ R. Torri

DASTU-Department of Architecture and Urban Studies,

Politecnico di Milano, Via Bonardi 3, 20133 Milan, Italy

e-mail: giuliana.costa@polimi.it

R. Cucca

Department of Sociology, University of Vienna, Roosveltplatz 2, 1140 Vienna, Austria

e-mail: roberta.cucca@univie.ac.at

R. Torri

e-mail: rtorri@polimi.it

(C) The Author(s) 2016

T. Brandsen et al. (eds.), Social Innovations in the Urban Context,

Nonprofit and Civil Society Studies, DOI 10.1007/978-3-319-21551-8_7 
solidarity networks and supports. A deep-rooted tradition stemming from a mediaeval religious principle defined "Milanese citizenship" as a status that anybody coming to the city could obtain by contributing to its welfare through work (Sabatinelli and Costa 2014; Costa and Sabatinelli 2013).

Until the 1980s (and since the end of WWII), Milan was also a highly dynamic context in terms of welfare provision, given that the municipal government was a very important actor in designing and providing social services, especially through huge investment in social and educational policies, sometimes also in some sort of competition with the national government (Agnoletto, 2006). This favourable situation started to change and deteriorate at the beginning of the 1990s, when the city was profoundly shaken by a far-reaching corruption scandal known as Tangentopoli (Bribesville). The "moral" capital of the country (so called also in opposition to Rome, the city of "opaque powers" and bureaucracy) thus in some way lost its image as the place where business and ethics went hand in hand.

After the political collapse of the early 1990s and the introduction of the direct election of mayors in 1993, ${ }^{1} 20$ years of centre-right local governments followed, first with a Northern League majority (1993-1997) and then for 14 years with mayors from Berlusconi's party (Costa and Sabatinelli 2013). In that period, the political coalition governing the city changed the approach to welfare. Social services started to be considered more as charitable actions for the most disadvantaged individuals than tools of social integration helpful for the economic growth of the city as a whole. Public expenditure devoted to sustaining the huge network of public services inherited from the previous administrations was increasingly considered to be more a cost for the local administration than a public investment for the social and economic development of the territory. In terms of local development, the city started to adopt "entrepreneurial" policies aimed at the maximization of property values, which closely mirrored the ideal type of pro-growth urban regimes (Harvey 1989). This was done especially through strategies of urban planning that favoured the use of land more for private investment than for public purposes (Molotch and Vicari 2009). Consistently with this approach, housing policies aimed at fostering affordability were almost abandoned for more than two decades, and this can be considered one of the most important institutional factors worsening the conditions of social and spatial inequalities in Milan, which is regarded as the most unequal city in Italy (D'Ovidio 2009) and one of the most unequal urban contexts in Europe (Cucca 2010).

Analysis of this transformation has been the focus of a large body of literature over the past decade, both in terms of social and economic trends (Ranci and Torri 2007; Bonomi 2009; Lodigiani 2010) and as regards the city's style of governance (Bricocoli and Savoldi 2010). In particular, as far as social policies are concerned, the literature has described how government coalitions boosted the use of some New Public Management instruments at municipal level, especially the contracting out or privatization of the provision of public and welfare services (Gori 2010). This fitted coherently with the frame being developed in the same years by the Lombardy region, which was characterized by the same continuity of centre-right coalitions (more specifically of Catholic inspiration; Gori 2005) emphasizing the

1 For municipalities with more than 15,000 inhabitants, based on a two-ballot system. 
creation of quasi-markets, users' freedom of choice, the centrality of families as the main actors in the fight against social exclusion, and the use of cash-for-care tools such as vouchers (Pesenti and Merlo 2012). Also important in this period was the political emphasis on security issues, which went along with countering migration flows and tightening illegal migrants' rights in terms of access to services either regulated at the local level (childcare services, school canteens, municipal housing) or delivered through national/regional programmes (health care; Sabatinelli and Costa 2014). As regards housing policies, scholars have highlighted the progressive reduction of initiatives in favour of the most marginal groups (Agustoni et al. 2012) also through stigmatization of the municipal housing stock as a place for migrants' segregation, which was replaced by a new interest in the housing needs of the new "vulnerable middle class" (Cognetti 2011; Bricocoli and Cucca 2014; Costa and Sabatinelli 2013). To sum up, this approach led to disinvestment in welfare services directly provided by the municipality in favour of a more residual welfare system based on the involvement of non-profit and private organizations and investment in market-oriented tools. The city's economic development through the promotion of international events (especially Expo 2015, see Costa 2014) and large real estate investments (Memo 2007; Anselmi 2013) moved to the forefront.

After scandals involving political actors, entrepreneurs, and also some non-profit organizations, as well as a huge and progressive increase of social inequalities in the city's social structure, the municipal elections brought a new coalition to power. In the spring of 2011, a major change took place in the local administration. A candidate from a small leftist party (Sinistra Ecologia e Libertà, SEL), Giuliano Pisapia, who conducted a campaign widely supported by grassroots movements, won the primary elections of the centre-left coalition against the official candidate of the main centre-left party (Partito Democratico, PD). As a mayoral candidate, supported by a coalition of eight centre-left political parties and civic lists, Pisapia later won the municipal elections against the outgoing centre-right mayor by calling for a new style of urban government more oriented to social justice and the wider participation of citizens in the decision-making process. "Participation" then became one of the watchwords of the new municipal administration, particularly in the field of social policies, as reported in the Development Plan for the Welfare of the City of Milan (2012). ${ }^{2}$

\footnotetext{
${ }^{2}$ Where one reads: "The City of Milan has decided to share the methods, resources, and risks of construction and implementation of what should be considered a real 'Strategic Welfare Plan'... [whose goal is] to move beyond the traditional logic of the Area Plan. This makes it possible to create a system of relationships and networks able to express, in a completely original way, social demands and the responses to them. One of the guiding principles for the construction and management of this local welfare plan is greater participation and the real involvement of all the protagonists of local society. In the area of personal services, it is necessary to enhance the wealth of knowledge, skills, and experiences that the city has accumulated over time. According to the original Ambrosiano spirit, we have to combine solidarity with creativity and the capacity to innovate. This comes with the idea of reallocating the resources available in order to fight fragmentation and promote 'social integration"' (p. 11, authors' translation).
} 
Against this background, the aim of this chapter is to fill a gap in the existing literature by describing some developments of the governance system in the field of social policies between 2011-2014. It focuses on the housing sector because of the importance of the problems related to housing affordability in Milan and to the shortage of public housing provision. In the next section, we describe the transition period that the welfare governance system is now undergoing, especially as far as values and policy discourse are concerned. We will concentrate on the previous social policies governance system in the city, the values and objectives characterizing the political coalition's welfare programme, and the governance system between 2011-2014. We will argue that the current situation represents a compromise between new values and plans for municipal welfare and the legacy of the past (especially in terms of financial budget constraints), and we will highlight continuities and discontinuities with previous administrations.

In the third section, we will focus on trends in Milan's housing policies in terms of governance and problematic issues, the purpose being to show why and how Milan is, according to the title given to this chapter, a city "lost in transition". In the concluding section, we will discuss how the current municipal government is dealing with the heavy financial legacy of the past and the barriers to promoting social innovation in housing and social policies according to the values that characterized the electoral campaign and its underlying political programme.

\subsection{The Changing Governance of Social Policies in Milan}

In this section, we analyse how the governance approach to local welfare has changed in Milan in recent years. Our focus is on the main transformations and on the obstacles to innovation that the current municipality is facing in governing and changing the city.

The last municipal elections represented an important turning point in terms of the rhetoric, values, networks of actors, and tools that have characterized the welfare system governance in Milan. However, as the chapter highlights, a range of interrelated factors are hampering social innovation processes and outcomes in the city.

One issue concerns the role that public regulation assigns to local welfare. At the national level, the legal framework in the field of social policy is defined by Law 328/2000, which is based on the logic of vertical and horizontal subsidiarity. ${ }^{3}$ This law introduced a cascade regulation pattern in which the state is responsible for the definition of general objectives and minimum assistance levels; regions are responsible for the planning and designing of social policies; provinces coordinate and support local levels; municipalities, also in associated form (social districts or ambits), are in charge of the implementation and delivery of services and supports

\footnotetext{
${ }^{3}$ This approach was confirmed by the 2001 constitutional reform, which strengthened this setting by introducing the concept of subsidiarity into the constitution (Constitutional Law 3/2001).
} 
(Barberis and Kazepov 2013). ${ }^{4}$ The principle of horizontal subsidiarity is instead interpreted as the engagement of the various social actors in the community through their involvement in both policy design and the provision of services.

The centrality of the regional level is particularly important in the case of Lombardy, where the regional government has over the years designed a welfare model with its own strong identity (Pesenti and Merlo 2012; Gori 2005). In general, the municipality of Milan in all its main pillars adopted this governance model until 2011. It is centred on the principle of horizontal subsidiarity (Pesenti 2007), and also on the leading role of the family as both supplier and consumer of services, which is recognized as comprising important social resources to be empowered and exploited (Gori 2005). Another pillar of this system is the freedom of choice for citizens as regards social services, which only need to be "accredited" by municipalities so that they can be implemented by the local social assistance system. Since the introduction of the regional law no. 3/2008 ("Government of the Network of Social and Socio-Medical Services"), the practical application of these principles has been founded on the implementation of services that are granted annually after winning a public tender. The new municipal coalition has in part challenged the regional approach to welfare, in particular with new keywords leading its action in the field of social policies: "a universalistic approach, not residual social policies" and "welfare as a tool to develop social capital". Within this framework, welfare is also described as "a tool for local economic development that cannot be removed merely by following the rhetoric of the financial crisis, because welfare enables people to be creative, business-oriented and productive..." (Milan Municipality 2012, p. 5).

Another important change concerns policy targets. Roughly, we can state that centre-right parties claimed that families should be the beneficiaries of policies, defining "family" as the one based on marriage; they systematically opposed any proposed reform to regulate de facto couples, and even more so gay marriages. Rejected by the former administration, a municipal register for equal rights and duties for all forms of family arrangements was promised and then introduced by Giuliano Pisapia in September 2012. Enrolment on this register permits whatever kind of couple to be recognized by the city council (in terms of housing, assistance, school, culture, and sports), also in order to combat all forms of discrimination (particularly those related to sexual orientation). ${ }^{5}$ The first practical effects are already apparent. For example, the municipal anti-crisis fund ${ }^{6}$ has been opened up to unmarried couples enrolled on the municipal register regardless of their sexual orientation (also, the requirement of 5 years of residence in the city has been removed).

\footnotetext{
${ }^{4}$ A recent national law (no. 56/2014) has introduced another level of government, the "Metropolitan City", which will require changes in terms of welfare policy planning. However, it is too early to state anything about this innovation.

${ }^{5}$ A delegate of the senator for equal opportunities was also appointed to deal with anti-discrimination issues.

${ }^{6}$ See Chap. 16 in this volume by Sabatinelli and Costa, "Fondazione Welfare Ambrosiano, Milan:

"We help you to help yourselves"'.
} 
Table 7.1 Social participation process architecture for design of the welfare plan. (Source: Milan Municipality 2012)

\begin{tabular}{|c|c|c|}
\hline & Conference & Actors \\
\hline \multirow[t]{2}{*}{$\begin{array}{l}\text { Intra-institutional } \\
\text { level }\end{array}$} & $\begin{array}{l}\text { Local social insurance } \\
\text { agency/municipality }\end{array}$ & $\begin{array}{l}\text { Representatives of the municipality and the } \\
\text { local welfare agency }\end{array}$ \\
\hline & Intra-departments & Municipal deputy mayors \\
\hline \multirow[t]{5}{*}{ Municipality } & "Local Welfare Tomorrow" & Young people under 30 \\
\hline & Citizens and associations & Citizens and associations \\
\hline & "Cultures of Welfare" & $\begin{array}{l}\text { Representatives of social services and } \\
\text { professionals }\end{array}$ \\
\hline & Neighbourhoods & Representatives of neighbourhood councils \\
\hline & Negotiation & Unions and employers' associations \\
\hline \multirow[t]{2}{*}{$\begin{array}{l}\text { Metropolitan region } \\
\text { and Italy }\end{array}$} & Large Italian municipalities & $\begin{array}{l}\text { Deputy mayors on social policies at } \\
\text { national level }\end{array}$ \\
\hline & Metropolitan municipalities & $\begin{array}{l}\text { Deputy mayors on social policies at } \\
\text { metropolitan level }\end{array}$ \\
\hline
\end{tabular}

However, it is mostly in terms of governance architecture that it is possible to recognize the greatest break with the past. Three years after the last municipal elections, the promotion of participation can be regarded as the main innovation in the local welfare system, while actions for more universalistic social policies have been blocked especially by the scarcity of funding. In terms of participation, close attention has been paid to the involvement of citizens and third-sector actors, mainly associations. Firstly, two editions of the municipal "Social Policies Forum" have taken place in preparation for the local 3-year social plan (Piano di Zona, foreseen by the national law 328/00 entitled by the present administration "Welfare Development Plan of the City of Milan 2012-2014"). Two editions of a participatory process linked to the "Milan Children" project on childcare and family policies have also taken place, ${ }^{7}$ as well as the recent first edition of the "Forum of Youth Policies" (named "MI Generation Camp"), as shown in Table 7.1. The feature shared by these events is the participative method, which is used with the declared aim of including organized groups and individual citizens in public agenda setting and decisionmaking. In some cases, these processes have explicitly included steps and events localized in the municipality's various districts.

This "participation turn" is a major difference with respect to the previous administration's approach, which predominantly consisted of hierarchical relations. It applied top-down decisions and transmitted information about changes already decided with little room for discussion and very few occasions for feedback and voice from the peripheral levels, such as the service-level workers, the beneficiaries/users/citizens, or the neighbourhood-level representative bodies. However, to 2014, the promotion of this large-scale process of participation has been the most important innovation. The local administration has made great efforts in implementing

\footnotetext{
${ }^{7}$ See Sabatinelli and Costa 2014.
} 
this process. However, at the same time, actions to create a more universalistic welfare system (with the exception of the institution of the municipal registers for common-law marriages, as mentioned above) have been more limited. This has been due to various factors.

The first concerns severe budget constraints due to the concurrence of several phenomena, in particular the financial crisis and the increase in social demands. Since 2008, the economic downturn has led to an increase in unemployment, in the use of short-time work schedules and in atypical and fixed-term contracts instead of open-ended ones (Costa and Sabatinelli 2012). Another reason relates to austerity measures as well as to the related cuts to transfers from the national level to local bodies. It has been estimated that, over the past 5 years, the total amount of funding from the national to regional level has decreased from 1231 billion $€$ in 2008 to 575 million $€$ in 2013, i.e. a reduction of 53.3\% (Polizzi et al. 2013). The third factor concerns the negative consequences of risky financial investments made by the previous administration that have further worsened the situation.

Moreover, it should also be stressed that the current local government has not always promoted welfare interventions as real priorities for the city, despite the efforts of the Social Policy Department to keep a decent budget. This attitude can be observed, for example, on analysing the municipality's approach to the Stability and Growth Pact. Contrary to other municipalities in Italy, Milan has made great efforts to respect the pact. ${ }^{8}$ These efforts have significantly affected the ability to cope with the negative social effects of the crisis. Given the insufficiency of public resources with which to respond to greater economic needs, especially third-sector and private actors have created solidarity funds and distributed forms of support, monetary and in-kind, to individuals and families hit by the recession. These funds are managed independently from the municipal administration.

It is, however, interesting to note that the municipal government instead pressed for a less restrictive pact in order to afford the development of infrastructural projects needed for the international Expo 2015. Expo 2015, indeed, can be considered the main significant project to promote the local economy in recent years.

Despite the great efforts of the local administration to open up the decisionmaking process through participation, the most important plans for the city's future (i.e. Expo 2015) and, to 2014, the priorities of the urban agenda have not been significantly changed.

Within this general framework, in the next section we focus on housing policies as a case study to illustrate the dynamics described above. We have selected housing because this policy area is extremely important for understanding the ambiguities that characterize the governance mechanisms of economic and social policies in Milan. However, housing policies have also been the area in which some of the most interesting cases of social innovation have occurred. In the next section, we

\footnotetext{
${ }^{8}$ In 2012, the mayor of Turin, for example, decided to depart from the Stability Pact in order to preserve more funding for local welfare, especially in this period of economic crisis and particular social vulnerability for citizens.
} 
describe the specific governance of the housing sector in Milan and analyse social trends and the main policies related to housing. We present a significant case of social innovation in this field and discuss its strengths and weaknesses.

\subsection{Affordable Housing Policies in Milan: Conflicting Narratives, Social Effects, and Governance Styles}

Milan is classified as a "high tension municipality concerning housing". Like other cities, it is subject to specific national and regional policy interventions, such as tax benefits for landlords that agree to rent out at prices lower than market ones or to postpone/suspend the eviction of tenants. For more than two decades, affordability problems in the housing sector have been disregarded by the local administration. This is because the housing market has been viewed as the main driver of the local economy's expansion, according to the neo-liberal notion of a "growth machine" where the public and private sectors merge in a shared consensus that the central function of a city is to grow (Logan and Molotch 1987). The Milan private housing market is considered one of the most effervescent in the country (Costa and Sabatinelli 2013). Since the early 2000s, it has been positively affected by the reconversion of many areas to residential use, after a broad and rapid process of deindustrialization in strategic semi-central neighbourhoods. A large number of urban transformation projects have been launched, many of them via the so-called Integrated Action Plans (Piani Integrati di Intervento, PII), which aim to accelerate the administration's approval of projects by providing exceptions to existing urban planning regulations. These large renewal programmes have been mainly based on property-led urban regeneration enabling the production of high-value housing in terms of the technology, size, and quality of the dwellings (Cognetti 2011; Mugnano and Palvarini 2011). Because of these characteristics, such dwellings are generally intended for medium-upper-class households and have very limited impact on a growing demand for affordable rental housing. The outcome of these processes has been the launch of approximately 150 urban transformation projects. In the coming years, this real estate development is likely to continue by using areas obtained from the sale of public properties and the conversion of land occupied by marshalling yards (Mugnano and Palvarini 2011).

The effect of introducing a high number of prestige housing units is an increase in total sales and the growth in sale and rental prices at the city level, not only in the areas developed. Also because of the presence of this prestigious and central segment of the housing market, the economic crisis (2007-2010) did not significantly affect house prices in Milan. In the past 10 years, prices have continued to increase (especially in the historic centre) with a pause only in 2008-2009, which was very limited compared with other cities and trends in international housing markets (OECD 2010; Costa et al. 2014). 
Nevertheless, housing issues have entered the public agenda because of the severe tensions in the market. While the centre-right local governments (1997/2011) intervened in the development to attract the affluent to the inner city, broader areas of the already-settled population-low- and medium-income households - have been made more vulnerable by the lack of affordable housing. As a consequence, growing amounts of young people, especially low-income ones leaving the parental households, have been expelled from the city. In the meantime, Milan has not yet been able to attract new residents. The inhabitants of the municipality increased by $0.6 \%$ between 2005 and 2010, while over the same period the provincial population grew by $3.2 \%$ and the regional population by $4.6 \%$ (Costa and Sabatinelli 2012). Moreover, the number of households with severe housing needs - such as extremely low-income households - has been increasing. In the period 2006-2009, the waiting list of households eligible for a public dwelling grew from approximately 13,000 to 20,500 (Costa and Sabatinelli 2012).

The recent global financial crisis and the ensuing long economic recession have exacerbated the problems by expanding the groups at risk of housing deprivation (Mugnano and Palvarini 2011). The number of families in difficulties with rent and loan repayments have increased. Eviction procedures - especially for arrearsstarted to grow again after 2006 with a huge acceleration in 2010, and they almost tripled between 2009 and 2010. In 2013, eviction proceedings numbered 11,700, of which 7600 were for rent arrears (Ministry of Interior, various years). In public dwellings, the arrears on total due revenues rose from $5.5 \%$ in 2001 to $10.2 \%$ in 2006 (Censis-Federcasa 2008) — an important indicator of the hardship suffered by the families resident in those dwellings.

In response to these pressures, the public housing stock-intended for households with severe housing needs - has progressively decreased owing to the lack of maintenance and the sale of significant amounts of units to tenants. The revenues raised from these sales have been mainly used to cover budget deficits, and they have only minimally been reinvested in the rehabilitation of social housing units or the construction of new ones. The overall public stock in Milan consists of 70,000 public housing units, 30,000 of which are intended for the lowest income groups (canone sociale), while approximately 18,000 eligible families are still on the waiting list. During 2010, only 700 public dwellings were assigned (Costa and Sabatinelli 2012). Moreover, housing benefits like rental subsidies for low-income families in private dwellings (Fondo Sostegno Affitto) have been reduced owing to the current phase of fiscal retrenchment. In this context, the public response to the affordability issue in Milan has mostly consisted in a new generation of policies and programmes called housing sociale. This new concept has had great influence on the public debate in the past decade (Plebani 2011), catalysing change and "innovation" in the housing policy field. Housing sociale is the way in which the Lombardy region reflects the new intent and concept of housing policy: Social housing is no longer conceived as permanent support for disadvantaged people in economic difficulties, rather, it is starting to be viewed as a service to help tenants emerge from 
a situation of uncertainty (Plebani and Marotta 2011). In this frame, social housing action is not directed to the weakest social groups, but is the instrument with which to respond to temporary critical housing situations of the middle classes.

This new approach has been mainly implemented in the Milanese context through exploitation of different urban planning regulations and tools, such as equalization in the "Transfer of Development Rights" (TDR), planning gains, and negotiations, which have recently been introduced in several municipal schemes. In this context, "social housing" mainly consists in a public-private partnership where the public actor provides building areas free of charge for private developers to build housing, which is partly to be rented or sold below the market prices. The public-private integration concerns both the actors and the resources although public participation is a small part of the total investment, which creates a "flywheel effect" for private initiatives. A large number of public areas have been made available to private investors in order to produce houses both for sale at fixed prices and as accommodation at moderate or social rents. In order to involve private operators, the State Property Office puts these areas, which were planned to provide public services and facilities, out to tender, but no rules have been introduced so that the private schemes provide for a quota of rented social housing (Pogliani 2011). For example, two of the main projects ongoing in the city centre do not comprise any public provision of social housing, which is provided by private operators, entirely to their advantage. In 2005 , the municipality launched the programme entitled " 20,000 housing units for social aims" to be developed on 46 publicly owned areas according to a scheme whereby land is given for free to developers under public bid procedures. In 2009, 3380 housing units (Abitare 1, 2, 3) were under project in 15 mixed neighbourhoods, where private developers, cooperatives, and third-sector organizations were involved. As we shall see below, a further 580 housing units in three neighbourhoods have been delivered by a bank foundation (Fondazione Cariplo). A total of 3960 housing units (instead of the 20,000 promised) have been constructed, but only one third of them (1200) for rent (Pogliani 2011).

As a matter of fact, the overall outcomes of this measure have been rather scant. On the one hand, the new stock provided a certain number of rental units affordable only by a small proportion of vulnerable households, the rent rate being not much less than the comparable market rate (called in Italian canone moderato). On the other hand, the number of social housing units affordable by low- and very-low-income families has been even smaller, if compared to the former, because developers have preferred to invest in more profitable high-quality housing. As a consequence, also the idea of "social mix" extensively used in the argumentative register of public action (Bricocoli and Savoldi 2014) has been very weakly promoted, given that the bulk of the new stock consisting of high-profile housing is to be sold on the private market. At present, and to sum up, one observes a sort of "polarized scenario" in the Milanese housing system, which is characterized, on the one hand, by the presence of housing exclusion or housing deprivation and, on the other, by a large proportion of well-housed people (Mugnano and Palvarini 2011). 
The most important innovative experience in this new field of housing sociale concerns the Fondazione Housing Sociale (FHS), a pioneering actor that created the first ethical fund for social housing in Italy, anticipating ad hoc legislation and policymaking (Costa and Sabatinelli 2013). The Fondazione Cariplo, the largest "foundation with a bank origin" in Italy, founded the FHS in 2004. Since 1999, it has tackled the issue of disadvantaged housing conditions by contributing to the realization of housing projects dedicated to the weakest segments of the population mainly through grants to third-sector organizations (Barbetta and Urbani 2007; Urbani 2009). Aware of the limited amount of resources available in the form of grants, the foundation decided to experiment with innovative financing instruments based on sustainability and ethical investments (and no longer on grants) in order to extend the range of social housing projects involving other public and private institutions and actors. The initiative thus took concrete form in the Social Housing Programme and the creation of the FHS, instituted to implement the former.

Supported by the Lombardy region and Anci Lombardia (the association of Lombardy municipalities), FHS plays an active role in the Italian real estate sector by taking an innovative approach to social housing as a way to handle diverse housing needs. It promotes access to housing by persons in the "grey area" (those who are not eligible for public housing but at the same time are not financially able to enter the private market), and it seeks to ensure the empowerment and social integration of residents. The work of FHS has been developed along three main axes: promoting ethical financing initiatives (and in particular real estate funds dedicated to social housing), testing innovative non-profit management models, and developing project design tools to be shared by trans-sectorial operators. The initial endowment by Fondazione Cariplo enabled the FHS to enter the real estate sector and create an ethical fund, the Fondo Abitare Sociale 1, in 2005. The fund was restricted to institutional investors such as public institutions, large firms, and bank foundations. Its purpose was to finance housing initiatives (new stock and services) aimed at supplying affordable rental dwellings by supporting the efforts of the public administration and the third-sector agencies, and with particular regard to students, elderly people, one-income families, migrants, young people, and, more generally, those unable to afford market prices to cope with their housing needs. The fund, now transformed and called the Fondo Immobiliare Lombardia (FIL) was open to "non-speculative investors" and assured yearly returns in the range of $2-4 \%$ plus inflation. The fund's investors have been described in the literature as "patient investors" (Giaimo 2011). The FHS's task is therefore a complex one: to encourage different actors to pursue common goals, attract investments in social housing projects, monitor their results, and develop sustainable management models that can be replicated in contexts other than Milan or Lombardy. In Italy, seeking sustainability mainly means finding economic and financial conditions that make social housing projects attractive not only to dedicated actors (like the FHS) or public ones but also to private actors. Accordingly, the FHS must and wants to be fully embedded in the local welfare system, in the awareness that its projects need to be supported by local 
authorities and partners that have (by mission or convenience) the same long-term horizon for investments.

Since the FIL was established, four projects have been developed in the municipality of Milan, namely Cenni di Cambiamento, Figino Borgo Sostenibile, Maison du Monde 36, and Abit@giovani. All these projects have been developed with the Milan municipality and are based on various public-private partnerships, as well as trying to respond to middle-class housing needs. ${ }^{9}$ At present, only one of these projects - Cenni di Cambiamento- has given rise to lived spaces. The project's final costs amount to around 21.7 million $€$, and 123 dwellings have been constructed, of which $40 \%$ are devoted to sustainable rent, $10 \%$ to social rent, $40 \%$ to rent-tobuy, while the rest have been granted to third-sector associations to be assigned or put out to tender by the Cariplo Foundation. The average monthly rent of a $70 \mathrm{~m}^{2}$ apartment is around $450 €$. Eligible applications (by persons with an annual income of less than 40,000 $€$, but 2.5-3 times higher than the annual rent) are almost three times greater than the supply. A protest by housing activists was staged on the occasion of the inauguration of the new buildings. Its purpose was to fight evictions and propose self-building and self-renovation practices instead of expensive social housing projects (national newspaper La Repubblica, local pages, November 2013).

The most positive aspects of this scheme (that need to be developed further for definitive conclusions to be drawn in terms of sustainability) have been the alignment of the FHS's policies with public ones, the enactment of public-private partnerships and resource pooling, the development of new models of social housing oriented to high building standards and focused social mix criteria (which is possible because of the derogation of allocation criteria for public dwellings), and, above all, the scaling up of the first ethical fund, which now is much wider and richer, and the inspiration for other contexts and groups of actors around Italy. But the case of the FHS should be read considering that it is backed by a very large and rich institution. Fondazione Cariplo is one of the biggest foundations in the world. In all its key initiatives, the FHS has been able to rely on Cariplo's resources, both financial and more intangible. Moreover, the FHS has been able to use some of the last empty plots to develop its projects thanks to conventions with the municipality of Milan. Social housing initiatives generally require complex management and the participation of different actors if they are to be attractive and compatible with private and public aims at the same time.

Some observers maintain that the FHS and the FIL are using their resources very slowly and that they are not risking enough to produce affordable dwellings. Moreover, they are using (like other operators) public resources (mostly public land) to produce too small amounts of housing to rent. Some criticisms are stronger, in the sense that they accuse subjects like the FHS of draining extremely scarce public resources from the most needy and deprived in the housing market (Sabatinelli and

\footnotetext{
${ }^{9}$ All of them aim to develop communities of residents that organize themselves to manage their spaces and common life.
} 
Costa 2013). Whatever the case, it can be stated that this experience has numerous shortcomings. Firstly, on the public land granted by the municipality (land that is extremely scarce in the city) very few affordable dwellings have been provided, especially if one considers the housing emergency in Milan. Secondly, this innovation is especially oriented to test social, functional, and tenure mix, while the housing emergency especially affects very-low-income citizens, who crowd the long waiting list to access the municipal housing stock.

After 3 years of the new municipal government, however, it is not possible to find other significant social innovation schemes in this strategic policy area. Numerous rhetorical discourses on the capacity of housing sociale to deal with housing needs have presented private actors and mixed ones (like the ethical funds) as a panacea for the city's housing problems. In fact, local difficulties are also represented by the resignation of the deputy mayor for housing policy in 2013 (who now represents the centre-left alliance in the regional council, governed by the centre-right), who tried, while in the municipality, to work on some important issues: among them, a new governance system for the municipal housing sector (with more responsibility for management of the stock given to the municipal government); the correct allocation of many vacant public dwellings; and experimental regulation of the private rental market. Instead, the main expectations for the future are now placed in the new Piano di Governo del Territorio (the urban planning instrument adopted in Lombardy cities), which imposes a very modest share of affordable housing units for new housing projects. However, it is quite probable that, owing to the critical situation of the construction sector in the city, few social housing units will be provided in the coming years.

To sum up, while a social innovation approach in housing policies is widely recognized in the case of the FHS by both the social innovators and the policy community at the local and the national level, we would highlight some general conditions that make policy innovation especially difficult to implement and spread in Milan.

According to Moulaert et al. (2005), social innovation is driven by history and the social context. This is partly structural, partly institutional determination. In regard to the institutional dimension, Milan has a legacy of social pluralism and multiple power centres, which has always engaged the municipality in constant confrontation with an array of economic interests and social issues. This fragmentation has hampered the capacity of the local administration to affirm an integrative and inclusive vision connecting the multifaceted networks of actors in Milan. Some argue that this lack of strategic governance capacity and the traditional weakness of formal government are offset by innovative capacities in the economy and civil society (Bolocan Goldstein 2009).

On the other hand, the lack of strategic governance and a poorly developed "public realm" within which the opportunities and challenges created by all these inventive actions can be retained generates the continuing neglect of many social issues and the ignoring of major future problems. Furthermore, multiple innovation and bottom-up initiatives tend to compete and clash with each other (Healey 2007). 


\subsection{Concluding Remarks: Local Development, Social Innovation, and Governance Alternatives}

In this chapter, we have described the transition of the ongoing welfare policies governance system in Milan over recent decades. Milan as a case study yields understanding of the barriers that local governments, especially in the countries most affected by the recession, face in promoting a system of governance oriented to social innovation, and in which social policies (even if weak) are supposed to play an important role in promoting local development. After many years of profound changes, Milan has currently reached deadlock in terms of policy innovation. From the 1950 s to the 1980 s, the city was highly dynamic in terms of welfare provision, given that the municipal government was a central actor in designing and providing social services as tools for economic and social development. From the 1990s to 2011, the municipal government instead played a weak role as director of a system of governance in which welfare was residual and was based on the involvement of non-profit and private organizations, but only as providers. During those two decades, the right-wing coalition governing Milan adopted a basically market-oriented style of governance (Molotch and Vicari 2009). The period was dominated by the rhetoric that creation of a "good business climate" was an effective way to foster growth and innovation but also to eradicate poverty and to deliver, in the long run, higher standards of living to the mass of the population (Harvey 1989). However, those years were marked by a huge increase in the social inequalities characterizing the social structure of the city (D’Ovidio 2009).

In 2011, municipal elections rewarded a new coalition proposing a style of governance more oriented to a "social innovation approach". However, the difficult financial situation inherited by the municipality from the past, and austerity measures imposed by the national government, have reduced the ambitions of the current municipal government in regard to social policies. In this chapter, we have highlighted that values expressed in the welfare plan have not yet been translated into effective actions. According to this document, for example, welfare measures are important investments for local development "that the rhetoric of the economic crisis is not supposed to limit" (Municipality of Milan 2012, p. 5). However, the efforts to respect the Stability Pact have greatly restricted welfare investments. Moreover, the municipal government has been pressurizing the national government to redesign the Stability Pact so that it was able to afford the public costs of the forthcoming International Expo 2015, while pressures to support welfare services have been weaker. Indeed, also the new municipal government regards this event as the main chance for the city's future economic and social development. Within the dimensions proposed by Cattacin and Zimmer in Chap. 2 of this volume, we can argue that Milan has been following a pattern of local development based on a concurrence of public investment in economic or social initiatives, while the rhetoric and values of the electoral campaign and the coalition programme have been more oriented to governance of social innovation. 
In fact, social innovation has to date been promoted mainly in some procedural aspects of governance (the large-scale participation in the definition of the welfare plan) and as regards certain social rights (the register to regulate de facto couples). Conversely, welfare provisions and services have not been innovated to a significant extent.

The analysis of housing policies as a case study highlights this situation very well. This is a policy field crucial for Milan because affordability problems are among the most important factors affecting social inequality and social exclusion in the city. However, this issue has long been neglected, while the real estate market has functioned as the driver of the city's economic growth. At the same time, this is also a sector where some interesting innovations involving private and nonprofit actors, such as the FHS, were proposed by the previous administration. This is an interesting case of "process innovation" because it emphasises a different way to provide affordable housing through new financing instruments and more collaborative and participative management models. On the other hand, some argue (Moulaert et al. 2005) that, in the current phase of welfare state retrenchment, the "product" dimension (provision of public services and redistributive measures) is re-emerging as a major issue. The lack of a clear, comprehensive strategy by the public administration to solve the urgent problem of providing affordable housing for low-income groups tends to undermine the innovative capacity of such projects, which are not fully recognized by people and are often criticized for creating a mismatch between the new supply (targeted on middle-income families and partly oriented towards home ownership) and a growing social demand for affordable housing (largely unsatisfied for low-income groups). Moreover, the strategy's potential for replicability and transfer is rather limited because of the unique conditions under which the projects described have been developed (above all, the financial role of the Cariplo Foundation, which guarantees against all potential risks and critical events). Furthermore, from the recent enforcement of laws and regulations at the central level (Legislative Decree 112/2008), a clear definition of what housing for the most vulnerable groups should be remains highly undetermined (social housing, subsidized housing or the Italian expressions "housing sociale" and Edilizia Residenziale Sociale designate with different emphases a way to provide affordable housing solutions to low-income households). Nor has the municipality of Milan spelled out a clear strategy to remedy this vacuum: a strategy to tackle inequalities and promote social inclusion at the local level risks being missed.

To sum up, Milan's situation describes a case of urban governance where no clear priorities are stated in terms of the city's social and economic development. Social innovation in Milan can be viewed as an array of largely disconnected and fragmented activities and projects. As far as housing policy is concerned, emerging innovative approaches (such as those described above) suffer from a lack of integration within common frames of reference, values, and orientations, which would make priority setting more objective, systematic, and transparent and impacts more clearly measurable. The city, pressured by the crisis and the austerity measures until the beginning of Expo 2015, has had little room for manoeuvre in defining a new municipal agenda that can significantly make the difference in comparison with the 
previous administration. In fact, the local government and other important actors in the city's governance system (such as third-sector agencies involved in social policies and entrepreneurs) have been heavily concentrated on the very difficult preparations for this international event (Costa 2014). Within this context, the desired transition to a style of government more open to social innovation and social justice has been "postponed", being affected by strong path dependency. Only after the end of Expo 2015, it will be possible to assess if the city will be able to recover the beneficial effects of a season of local mobilization in favour of a more inclusive approach to social innovation. Some recent programs launched by the Social Policy Department and the Department for Innovation and Labour Market Policies seem to be oriented towards this direction.

Open Access This chapter is distributed under the terms of the Creative Commons AttributionNonCommercial 4.0 International License (http://creativecommons.org/licenses/by-nc/4.0/), which permits any noncommercial use, duplication, adaptation, distribution and reproduction in any medium or format, as long as you give appropriate credit to the original author(s) and the source, a link is provided to the Creative Commons license and any changes made are indicated.

The images or other third party material in this chapter are included in the work's Creative Commons license, unless indicated otherwise in the credit line; if such material is not included in the work's Creative Commons license and the respective action is not permitted by statutory regulation, users will need to obtain permission from the license holder to duplicate, adapt or reproduce the material.

\section{References}

Agnoletto, S. (2006). Capacità di government pubblica e politiche di welfare a livello locale: l'amministrazione comunale di Milano negli anni 50 e 60. Bollettino dell'Archivio per la Storia del Movimento Sociale Cattolico in Italia, 2, 181-220.

Agustoni, A., Alietti, A., \& Cucca, R. (2012). Social housing policy as a tool for ethnic integration in Europe. A critical view on the Italian experience. In H. Bauder (Ed.), Immigration \& settlement: Challenges, experiences and opportunities in global and local contexts. Toronto: Canadian Scholars Press.

Anselmi, G. (2013). Milano 1997-2011: Una growth machine all'italiana? https://unimib.academia.edu/GuidoAnselmi.

Barberis, E., \& Kazepov, Y. (Eds.). (2013). Il welfare frammentato. Le articolazioni regionali delle politiche sociali italiane. Roma: Carocci.

Barbetta, G. P., \& Urbani, S. (2007). L'housing sociale e le fondazioni. In A. Rigon \& F. Sbetti (Eds.), Fondazioni, politiche immobiliari e investimenti nello sviluppo locale. Venezia: Marsilio.

Bolocan Goldstein, M. (2009). Geografie milanesi. Santarcangelo di Romagna: Maggioli.

Bonomi A. (2009). Milano nell'Expo. La città tra rendita e trasformazioni sociali, ShaKe.

Bricocoli, M., \& Cucca, R. (2014). Social mix and housing policy: Local effects of a misleading rhetoric. The case of Milan. Urban Studies, 1-15, doi:10.1177/0042098014560499.

Bricocoli, M., \& Savoldi, P. (2010). Milano downtown. Luoghi dell'abitare e azione pubblica. Milano: Et al./Edizioni.

Bricocoli, M., \& Savoldi, P. (2014). Urban space as public action "Made Durable": Open spaces and urban change in Milan. In A. Madanipour, S. Knierbein, \& A. Degros (Eds.), Public space and the challenges of urban transformation in Europe. New York: Routledge.

Censis-Federcasa. (2008). Social Housing e agenzie pubbliche per la casa. http://www.federcasa.it. Cognetti, F. (2011). Quale politica per l'abitare? Urbanistica, 131, 11-17. 
Costa, G. (2014). Impatti e legacy sociali dei grandi eventi, esperienze internazionali, sfide e opportunità per Milano 2015. In R. Lodigiani (Ed.), Milano 2014 Rapporto Ambrosianeum sulla Città, Expo, Laboratorio metropolitano, cantiere per un mondo nuovo (pp. 111-133). Milano: Franco Angeli.

Costa, G., \& Sabatinelli, S. (2012). City Report: Milan, WILCO Publication 18. http://www.wilcoproject.eu/public/assets/img/uploads/WILCO_WP3_Brescia_18.pdf.

Costa, G., \& Sabatinelli, S. (2013). WILCO WP4 Milan Report. http://www.wilcoproject.eu.

Costa, G., \& Sabatinelli, S. (2014). Brescia. In A. Evers, B. Ewert \& T. Brandsen (Eds.), Social innovations for social cohesion. Transnational patterns and approaches from 20 European cities. Liége: EMES European Research Network asbl.

Costa, G., Palvarini, P., Bezovan, G., \& Brandsen, T. (2014). Urban housing systems in times of crisis. In T. Brandsen, S. Sabatinelli, \& C. Ranci (Eds.), Social vulnerability in European cities. The role of local welfare in times of crisis. Basingstoke: Palgrave.

Cucca, R. (2010). Crescita diseguale. Gli impatti sociali della transizione al post-fordismo nelle città europee. In C. Ranci (Ed.), Città nella rete globale. Competitività e disuguaglianze in sei città europee (pp. 79-115). Milano: Bruno Mondadori.

D’Ovidio, M. (2009). Milano, città duale? In C. Ranci (Ed.), Milano e le città d'Europa tra competitività e disuguaglianze (pp. 9-72). Santarcangelo di Romagna: Maggioli Editore.

Giaimo, C. (2011). Edilizia sociale e piano urbanistico: risorse, soggetti e progettualità. Urbanistica, 242, 10-11.

Gori, C. (2005). Politiche sociali di centro-destra. La riforma del welfare lombardo. Roma: Carocci.

Gori C. (2010). A cura di. Come cambia il welfare lombardo: una valutazione delle politiche regionali, Maggioli, Milano.

Harvey, D. (1989). From managerialism to entrepreneurialism: The transformation in urban governance in late capitalism. Geografiska Annaler. Series B, Human Geography, 71(1), 3-17.

Healey, P. (2007). Urban complexity and spatial strategies: Towards a relational planning for our times. London: Taylor \& Francis.

Istat (National Institute of Statistics). http://en.istat.it/.

Lodigiani, R. (2010). Rapporto sulla città. Milano 2010. Welfare ambrosiano, futuro cercasi. Milano: Franco Angeli.

Logan, J. R., \& Molotch, H. (1987). Urban fortunes: The political economy of place. Berkeley: University of California Press.

Memo, F. (2007). Nuove caratteristiche del sistema immobiliare e abitabilità urbana. Alcune evidenze a partire dal caso di Milano. Sociologia Urbana e Rurale, 84(1), 103-123.

Milan Municipality. (2012). Piano di Sviluppo del Welfare della Città di Milano. http://www. milano.comune.it.

Molotch, H. (1993). The political economy of growth machines. Journal of Urban Affairs, 15, $29-53$.

Molotch, H. (1999). Growth machine links: Up, down, and across. In A. E. G. Jonas \& D. Wilson (Eds.), The urban growth machine: Critical perspectives two decades later. Albany: State University of New York Press.

Molotch, H., \& Vicari, S. (2009). Three ways to build the development process in the United States, Japan, and Italy. Urban Affairs Review, 24(2), 188-214.

Moulaert, F., et al. (2005). Towards alternative model(s) of local innovation. Urban Studies, 42(11), 1969-1990.

Mugnano, S., \& Palvarini, P. (2011). How Milan housing market is responding to the financial crisis? Paper presented at ENHR Conference 2011, 5-8 July, Toulouse.

OECD (2010). Employment outlook 2010. Moving beyond the jobs crisis.

ORIM - Osservatorio Regionale per l'Integrazione e la Multietnicità. (2011). Gli Immigrati in Lombardia, decimo rapporto.

Pesenti, L. (2007). Politiche per l'inclusione: caratteristiche e prospettive. In IRER (Ed.), L'esclusione sociale in Lombardia. Caratteristiche, risposte e politiche (pp. 171-178). Milano: Guerini Editore. 
Pesenti, L., \& Merlo, F. (2012). Il futuro della programmazione sociale in Lombardia. In L. Pesenti \& F. Merlo (Eds.), Verso un nuovo welfare locale e plurale. Milano: Guerini \& Associati.

Plebani, F. (2011). Housing sociale e futuro delle politiche abitative. Autonomie locali e servizi sociali, 3, 389-406.

Plebani, F., \& Marotta, V. (2011). Ethical Social Fund: A Lombardy solution to finance Social Housing. Paper presented at ENHR Conference 2011, 5-8 July, Toulouse.

Pogliani, L. (2011). Key players in the Social and Affordable Housing provision in Italy. Paper presented at ENHR Conference 2011, 5-8 July, Toulouse.

Polizzi, E., Tajani, C., \& Vitale, T. (2013). Programmare i territori del welfare. Attori, meccanismi ed effetti. Roma: Carocci.

Ranci, C., \& Torri, R. (2007). Milano tra coesione sociale e sviluppo. Primo Rapporto su Milano sociale. Milano: Bruno Mondadori Editore.

Sabatinelli, S., \& Costa, G. (2014). Milan. In A. Evers, B. Ewert, \& T. Brandsen (Eds.), Social innovations for social cohesion. Transnational patterns and approaches from 20 European cities. Liége: EMES European Research Network asbl.

Santaniello, F. (2008). Social housing and local systems. A research about effectiveness in non profit intervention in Milan. Paper presented at XI EURA Conference, Milan, October 9-11.

Tosi, S. (2007). La legislazione come strumento. In R. Monteleone (a cura di) (Ed.), La contrattazione nelle politiche sociali. Forme ed effetti. Roma: Officina Edizioni.

Urbani, S. (2009). I fondi immobiliari per l'edilizia sociale. In R. Delli Santi \& S. Mantella (Eds.), Capital Market e Real Estate. Milano: Egea.

Vicari, S., \& Molotch, H. (1990). Building Milan: Alternative machines of growth. International Journal of Urban and Regional Research, 14, 602-624. 